\title{
PRSS8 wt Allele
}

National Cancer Institute

\section{Source}

National Cancer Institute. PRSS8 wt Allele. NCI Thesaurus. Code C50374.

Human PRSS8 wild-type allele is located in the vicinity of $16 \mathrm{p} 11.2$ and is approximately 4 $\mathrm{kb}$ in length. This allele, which encodes prostasin protein, is involved in the cleavage of proteins in seminal fluid. 